\title{
Forest resources use, attitude, and perception of local residents towards community based forest management: Case of the Makira Reducing Emissions from Deforestation and Forest Degradation (REDD) Project, Madagascar
}

\author{
Cynthia Lalaina Ratsimbazafy*, Kazuhiro Harada and Mitsuru Yamamura \\ Graduate School of Human Sciences and Environment, Hyogo University, 1-1-12, Shinzaike-honcho, \\ Himeji, 670-0092 Hyogo, Japan. \\ Accepted 22 August, 2012
}

\begin{abstract}
Community participation is seen to be the building block for the efficiency of the Reducing Emissions from Deforestation and Forest Degradation (REDD) project. In order for local residents to cooperate with a reduction of deforestation and forest degradation, they must have a positive perception toward the forest conservation system and positive attitude toward the forest conservation project. This study examined the attitude and perception of the local community toward conservation of the Makira forest, from where carbon credits are intended to be sequestered under the REDD schema. The perception and attitude of the local people were studied in three dimensions: the perception toward the conservation of Makira, the perception of the forest and forest resources, and the perception of the community forestry including cost and benefit. It was assumed that regardless of the dependency of local residents on the forest, the reception of an incentive and participation in the local meetings or participation within the forest conservation and development activities would provide a positive perception toward the forest conservation project. Data were obtained from a random sample of 188 households living within the vicinity of the protected forest. Sixty percent of respondents were found to agree with the idea of Makira forest conservation; however, statistically significant differences were found between the villages in terms of supportive attitudes toward the forest conservation system $(p=0.03)$ and toward the conservation project $(p=0.04)$. Nearly half of the respondents held a positive attitude toward the conservation project. However, those highly dependent on the forest to generate income remained reluctant and unsupportive, suggesting that high levels of support toward a conservation project by sections of the community may not translate into conservation success, because the drivers of the deforestation and forest degradation are not supportive. A perception of direct benefits from the project was found to be the main factor of the respondents' attitudes and perceptions. This study then suggests that to change the perception and attitudes of indigenous people around protected areas, environmental education through sensitization should be encouraged, and then addressing local development needs, encourage broader participation in community forestry if the conservation project wants to win the support of local communities for long-term emission reduction through forest conservation goals.
\end{abstract}

Key words: Protected area, forest management, community attitude, Makira, Reducing Emissions from Deforestation and Forest Degradation (REDD).

\section{INTRODUCTION}

Several mechanisms have been instituted to mitigate climate change by protecting the forest; these include voluntary mechanisms and the United Nations Framework Convention on Climate Change (UNFCCC) mechanism. 
For example, under the Reducing Emissions from Deforestation and Forest Degradation (REDD) mechanism, all tropical countries are attempting to protect their natural forest to the maximum possible extent by establishing protected areas (PA) or give forests another protective status. However, the forest, before being targeted for carbon enhancement, is an important source of livelihood for the local poor inhabitants. PAs have brought consumptive and non-consumptive benefits (Harada, 2003), and it is estimated that $90 \%$ of the world's poor depend on forests for at least a portion of their income (World Bank, 2000; Scherl et al., 2004; USAID, 2006). In Africa alone, 600 million people have been estimated to rely on forests and woodlands for their livelihoods (Anderson et al., 2006).

Since 2003, following the declaration by a former president at the Durban World Park Congress concerning the engagement of the country in protecting its remaining forest as a responsive measure to remediate climate change, a large area has been set aside as future PAs across the remaining natural forest of Madagascar. Since then, the PA has increased from 1.7 million hectare (Mha) to nearly 7 Mha by 2010 (SAPM, 2010). Five projects were created and implemented within 1.8 Mha under the REDD, and from this, 45 million tons (Mt) of carbon dioxide $\left(\mathrm{CO}_{2}\right)$ are expected to be sequestered and sold by 2038 on the voluntary carbon market. A key difference between these newly created PAs and the previous PAs is that the old PA were generally based on strict conservation system mainly managed by the forest administration and its agencies, in fact, the new PAs have diversified stakeholder as manager and diversified management system that varied according to the management objectives, also, the new PAs have numerous residents within their border (Fergusson, 2009).

It is already widely acknowledged that communities living within the vicinity of the PA are critical to the success of conservation efforts (Agrawal and Gibson 1999; Ferraro, 2002; Ostrom, 1999; Robertson and Lawes, 2005; Wiggins et al., 2004), as such, the attitudes of local residents and the level of local participation, as well as the conflicts between people and the PAs have become a concern for PA effectiveness (West and Brechin, 1991; Wells and Brandon, 1992; Western and Wright, 1994; Pimbert and Pretty, 1995; Kramer et al., 1997; Stevens, 1997; Brandon et al., 1998; Alison et al., 2005). Several studies have attempted to analyze the factors that determine the attitudes of local people toward a given forest conservation program, and these studies typically have correlated perceptions, attitudes, conservation, and the purpose and benefits of the PA with a variety of

\footnotetext{
*Corresponding author. E-mail:

Ne09r005@stshse.u-hyogo.ac.jp Tel: +81-79-292-9393. Fax: +81-79-293-5710.
}

socio-demographic factors (Infield, 1988; Newmark et al., 1993; Ormsby, 1996; Mehta and Kellert, 1998; Gillingham and Lee, 1999). This study attempted to examine the attitudes of the local people involved in the forest conservation project where carbon credits are targeted to be sequestered. The case study was done for the Makira project, from where $9 \mathrm{Mt}$ of $\mathrm{CO}_{2}$ are intended to be sequestered by 2034 under the REDD mechanism. Three factors were selected to understand the attitudes of the local people toward the forest conservation system and the forest conservation project: the perception toward the conservation of Makira, the perception of the forest and forest resources, and the perception of the community forestry including cost and benefit.

\section{RESEARCH METHODS}

\section{Description of the study area}

This study was conducted within the Makira forest conservation project, which is located in the North Eastern section of Madagascar, $15^{\circ} 25^{\prime}$ south latitude and $49^{\circ} 30^{\circ}$ east longitude. The PA is implemented within the 371,800 ha of forest area. The ecosystem type is low altitude rainforest. Agriculture is the main source of livelihood for the local people. Approximately 50,000 people, distributed across 120 villages in and around the Makira forest, directly depend upon the forests for ecosystem services and land for their livelihood (Holmes and Crowley, 2007). Rice cultivation is the main agricultural activity, followed by other cash crops, such as beans, cloves, and vanilla. Generally, the area is characterized by a high poverty rate, which is driven by poor market access, low levels of education, and high population growth rates. The annual population growth rate is estimated to be $3.2 \%$ per year (Meyers, 2008).

Due to these factors, the main threats facing the Makira forest are swidden agriculture, bush meat hunting, collection of non-timber forest products, burning of forest land for cattle grazing, illegal logging of hardwood species, and illegal mining of quartz and precious stones (Jaozandry and Holmes, 2005). The sale of $\mathrm{CO}_{2}$ from avoided deforestation through the growing carbon market may represent a unique opportunity to reconcile natural resource conservation and poverty reduction in the area (Holmes, 2007).

\section{Governance system of Makira and community participation}

The main strategy to manage the Makira PA is the collaborative approach between the three main stakeholders involved, first, the forest administration is the owner of the forest and at the local level, the forest administration is represented by the local administration including the mayor and the village leader. The second stakeholder is the Wildlife Conservation Society (WCS), which acts as the project developer and manager. The third stakeholder is the local community, which is organized as an association that is locally known as Communauté de base (COBA). The forest management contracts were basically established between COBA and the local administration with the project manager. The contract included the delimitation of the area that can be accessed by the COBA as well as additional resource access rules. As required by the regulation, all stakeholders including local community were consulted in all actions to be taken regarding the forest conservation. Each minute of the meetings held, were displayed on a board in each village for all inhabitants to consult and thus submit their remarks or complain. In fact, the idea of the REDD and the information surrounding the REDD were not disclosed yet to the community member, only those that were selected to represent the local community at regional and 
Table 1. Demographic and socioeconomic characteristics of the respondents.

\begin{tabular}{|c|c|c|c|c|c|c|c|}
\hline Characteristic & V1 $(n=44)$ & V2 $(n=46)$ & V3 $(n=52)$ & V4 $(n=46)$ & $x^{2}$ & df & $p$ \\
\hline \multicolumn{8}{|l|}{ Age } \\
\hline Young: $<30$ & 6 & 8 & 10 & 10 & \multirow{4}{*}{8.510} & \multirow{4}{*}{9} & \multirow{4}{*}{0.49} \\
\hline Middle age: $30-40$ & 16 & 15 & 17 & 14 & & & \\
\hline Elder: 41-54 & 12 & 11 & 10 & 18 & & & \\
\hline Old: $>55$ & 10 & 12 & 15 & 4 & & & \\
\hline \multicolumn{8}{|l|}{ Years of schooling } \\
\hline 0 & 11 & 10 & 10 & 7 & \multirow{4}{*}{12.614} & & \multirow{4}{*}{0.18} \\
\hline $1-5$ & 27 & 23 & 24 & 23 & & \multirow{3}{*}{6} & \\
\hline $6-9$ & 6 & 10 & 11 & 10 & & & \\
\hline$\geq 10$ & 0 & 3 & 7 & 6 & & & \\
\hline \multicolumn{8}{|l|}{ Landholding } \\
\hline$<2$ & 35 & 19 & 18 & 23 & \multirow{3}{*}{19.550} & \multirow{3}{*}{9} & \multirow{3}{*}{0.02} \\
\hline $2-4$ & 8 & 23 & 24 & 16 & & & \\
\hline$>4$ & 1 & 4 & 10 & 7 & & & \\
\hline \multicolumn{8}{|c|}{ Annual cash income (in USD) } \\
\hline$<250$ & 18 & 8 & 6 & 11 & \multirow{4}{*}{14.309} & \multirow{4}{*}{9} & \multirow{4}{*}{0.04} \\
\hline $250-350$ & 18 & 14 & 19 & 13 & & & \\
\hline$>350-450$ & 8 & 16 & 13 & 16 & & & \\
\hline$>450$ & 0 & 8 & 14 & 6 & & & \\
\hline \multicolumn{8}{|l|}{ Wealth stratum } \\
\hline Poor & 12 & 25 & 25 & 15 & & & \\
\hline Medium & 26 & 10 & 7 & 17 & 15.384 & 6 & 0.03 \\
\hline Better off & 6 & 11 & 20 & 14 & & & \\
\hline Family size & 7 & 6 & 7 & 7 & 14.287 & 9 & 0.112 \\
\hline
\end{tabular}

national consultation were aware about the REDD, thus the community attitude and perception toward the REDD itself is less relevant in this research.

\section{Study method}

This study was conducted from November, 2010 to January, 2011. Although, approximately 40 villages represented by the COBA had fulfilled the management contract, four villages were selected to conduct the survey, including Andaparaty (V1), Ambodivoangy (V2), Marovovonana (V3), and Ambalamahogo (V4). The criteria of selection were based on the seniority of the management transfer (more than 5 years) and implementation of the development activities. The primary data were collected through the administration of open- and closed-ended questionnaires that were given to 188 selected individuals. Stratified random sampling was applied to carry out the selection. The households were selected after close consultation with the staff from the project developer, the COBA leader and the villages' leaders based on: their membership within the COBA and their wealth stratum. The sampled households represented $13.2 \%$ of the total households in the selected villages.

Both qualitative and quantitative approaches were used. A qualitative approach was adopted, with a series of question formulated on various aspects of the forest conservation system and the local people participation, while a quantitative approach was used to study the relationship between perceptions and dependency on forest resources, and the relationship between the benefits received and the attitude to the project. The questionnaire had three sections: (i) information on demographic and socio-economic profiles, (ii) perceptions of forest conservation cost, benefits, and attitudes, and (iii) perceptions toward the forest conservation project. The socio-economic factors recorded were age, gender, year of education, source of income, and involvement in the local associations. Analysis of the results was conducted using Statistical Package for Social Sciences (SPSS) version 19.0 (IBM, USA). The relationship between dependency on the forest resource and individual attitude questions, and between participation and benefit distribution were analyzed using the Pearson chi-square test, while logistic regression was used to identify the variable associated with the positive attitude toward the forest conservation system. A $p \leq$ 0.05 was considered statistically significant.

\section{RESULTS}

\section{Characteristics of the selected samples}

During the field study, 104 men (55\%) and 84 women $(45 \%)$ were interviewed. Of these, $17 \%$ of the respondents were between 25 and 29 years of age, 35\% of the respondents were between 30 and 40 years of age, $30 \%$ respondents were between 41 and 55 years of age, and $18 \%$ were above 55 years of age (Table 1). As a 
Table 2. The perception of local people of the forest.

\begin{tabular}{ccccc}
\hline \multirow{2}{*}{ Perception } & \multicolumn{4}{c}{ Perceived use of the forest (\%) } \\
\cline { 2 - 5 } & Sample size & Protective use & Productive use & No importance \\
\hline V1 & 44 & 25.0 & 56.8 & 18.2 \\
V2 & 46 & 52.2 & 23.9 & 23.9 \\
V3 & 52 & 44.2 & 38.5 & 9.6 \\
V4 & 46 & 39.1 & 50.0 & 10.9 \\
Total & 188 & 39.9 & 42.0 & 18.1 \\
\hline
\end{tabular}

The difference in perception between villages was statistically significant $\left(x^{2}=14.02, \mathrm{df}=6, p=\right.$ 0.03).

result, $67 \%$ of the respondents were between 30 and 55 years of age which is representing most productive age group. Twenty five percent of the respondents were illiterate, $52 \%$ went to primary school then dropped, $14.4 \%$ went to junior high school, and $8.6 \%$ went to high school. Close to $75 \%$ of the respondents then received at most five years of education. This low level of education has limited the involvement of the local people in the REDD implementation process.

Eighty percent of the livelihood sources of the surveyed household were from subsistence agriculture; however, people that received higher education had other considerable sources of income, such as store ownership, local business, or a public profession, mainly teaching. The agricultural land ownership varied from 0.7 to $4 \mathrm{ha}$, of which $83.8 \%$ of the respondents owned between 1.5 and 3 ha. The source of cash income mainly came from livestock (49\%), small business (5\%), and crop trade $(46 \%)$. The wealth stratum of the studied household was classified using score ranking according to the following criteria:

1. If household owns more than 4 ha of land, secured food with surplus, then wealth rank is " 3 " better off.

2. If the household owns less than 4 ha of land, food is secured all the year, but without surplus then wealth rank is " 2 " medium class.

3. If the household own less than 2 ha of land, unsecured food during some months of the year, then the wealth rank is " 1 ", poor

According to this classification: $41 \%$ of the surveyed households were poor, $32 \%$ were medium class, and $27 \%$ were better off. Characteristically, poor households were those who reported insufficient annual income and insufficient crop production to support the basic expenditures of the household, such as food, clothes, education, and medicine. Among the basic socioeconomic criteria, there were significant differences among villages regarding land holding $(p=0.02)$, average annual income $(p<0.01)$, and wealth stratum $(p=0.02)$. The average size of land held by households living in the V2 and V3 was higher than V1 and V4 (2.1 and 2.3 ha versus 1.3 and 2 ha, respectively), which was essentially determined by the topographical characteristics of the villages. In addition, the households in V2 and V3 had more diversified sources of income and a considerable quantity of rice, resulting in those households being wealthier than the households in V1 and V4.

\section{Perception of local people of the forest}

In total, $41.5 \%(n=78)$ of the interviewed people perceived the forest as a source of rain and as a resource for maintaining the fertility of the land, and therefore worth protecting (Table 2).

Importantly, the percentage of people who thought that the forest was worth protecting was statistically different between the four villages $(p=0.03)$. The respondents who perceived the protective use of the forest were mainly older ( $>55$ years old) $(p=0.04)$. The old respondents and the more educated people were generally more aware about the ecosystem function of the forest and were concerned about the consequences of completely clearing the forest.

Of the interviewed local residents, $43.6 \%(n=82)$ perceived the forest as an important source of supplemental income and agricultural land, and of these, majority (64\%) were young and middle aged men who depended entirely on agriculture plus some cash from the forest resources. Fifteen percent of the respondents $(n=$ 24) claimed that the forest did not have any importance regardless of protection, of this, $79.1 \%(n=19)$ were women.

\section{Local resident's use of forest resources}

Regardless of the socioeconomic characteristics or the village where the residents lived, firewood was the main source of energy in the study areas $(p=0.87)$. In addition, nearly $99 \%$ of the material for housing came from the forest, such as thatch for roofing material and timber for the house and furniture. As Table 3 demonstrates, the use 
Table 3. Forest resource use in the selected villages.

\begin{tabular}{lccccccc}
\hline Resource & V1 (\%) & V2 (\%) & V3 (\%) & V4 (\%) & $\mathbf{X}^{\mathbf{2}}$ & df & p \\
\hline Fuel wood & 99.1 & 97.9 & 98.8 & 98.7 & 1.75 & 19 & 0.86 \\
Hardwood for construction & 98.6 & 94.6 & 96.4 & 97.3 & 0.50 & 3 & 0.92 \\
Conversion Forest land for agriculture & 71.4 & 44.7 & 40.5 & 72.1 & 21.1 & 12 & 0.04 \\
Medicinal plant & 64.3 & 39.5 & 37.8 & 32.6 & 19.2 & 3 & 0.02 \\
Bush meat & 52.4 & 31.6 & 24.3 & 48.8 & 17.8 & 9 & 0.04 \\
Other edible(Fruit, yam, green leaves) & 30.9 & 13.0 & 17.3 & 26.1 & 18.4 & 9 & 0.03 \\
Mine & 13.6 & 13.1 & 23.1 & 26.1 & 16.0 & 18 & 0.03 \\
Hardwood for commerce & 13.6 & 8.7 & 23.1 & 19.6 & 16.4 & 12 & 0.05 \\
Fiber & 7.1 & 21.0 & 8.10 & 9.3 & 14.9 & 12 & 0.25 \\
\hline
\end{tabular}

of timber did not differ between villages $(p=0.76)$, but did differ widely by gender $(p<0.01)$, age $(p<0.01)$, land ownership ( $p=0.02)$, and wealth stratum $(p<0.01)$. In addition to the use of timber for housing, middle age and elderly men that owned more land and were socioeconomically well off $(21.3 \%$ of the total respondents surveyed) tended to use a larger quantity of timber, which was mainly for carpentry, traditional boat manufacturing, livestock housing, and timber trade.

The harvest of fiber and edible resources was significantly higher for women $(p<0.01)$ and differed within villages $(p=0.04)$. Respondents from V1 and V4 tended to harvest more edible resources from the forest than the other two villages (Table 2$)(p=0.04)$, which was related to the high proportion of landless and poor households in V1 and V4 that relied on the forest to bridge the gap between household need and available crops during the latent period $(p=0.02)$. Honey, fruits, and yam were dietary supplements, and green leaves were used for daily food and medicine in some cases. Fiber were used for handicraft, and its use did not differ between villages $(p=0.25)$.

Mine extraction represented a considerable source of income for some households in the study area, and $22.96 \%$ of the respondents extracted mostly gold and quartz from the forest areas. The percentage of respondents who mined was different between the villages $(p=0.03)$, age $(p<0.01)$, and education level ( $p$ $<0.01$ ). Of the respondents who mined, $88 \%$ were 30 to 40 years old and were most likely illiterate or went to primary school but dropped.

Concerning the forest land, $57 \%$ of the surveyed respondents reported that half or more of their land was located inside the forest, which were lands that were a result of the slash and burn practice and mainly used for rain-fed rice cultivation and other crops, such as cloves and vanilla. The percentage of the respondents that depended on forest land differed between villages $(p=$ 0.04), and respondents from V1 and V4 had more dependence on forest land $(71 \%$ and $72 \%$, respectively). This observation can be explained by the topographical and socioeconomic context of the villages.

\section{Perception of local people toward the Makira forest conservation}

Of the respondents questioned, $83 \%$ agreed that the forest area had declined and $71 \%$ agreed that the decline of the forest had an impact on their livelihood. Regardless of the village or socioeconomic characteristics, all interviewed people were aware of the existence of the Makira PA; $60.5 \%$ were in favor of conservation of the Makira forest, and $60.5 \%$ agreed that it was the local community's responsibility to safeguard the forest in their surroundings. Nevertheless, as illustrated in Table 4, the number of responders that agreed or disagreed about the forest resource accesses restriction measure was significantly different between villages $(p=0.03), 59$ and $54 \%$ of the respondents from the $\mathrm{V} 1$ and $\mathrm{V} 4$, respectively did not favor the implementation of restrictive measures toward the access to forest resources, while 63 and $57 \%$ of the respondents from V2 and V3, respectively, indicated that implementing restrictive measures was necessary to sustain the resources. This difference in perception can be explained by the fact that the local people in V1 and V4 had less diversified sources of income, and therefore the forest played a considerable role in the livelihood of these residents, either from direct resources, such as logging or mining, or from conversion of forest land for agricultural purposes. In addition, 59\% of the interviewed people did not favor the implementation of a strict conservation zone that covered $70 \%$ of the total area of the project.

These respondents claimed that the strict conservation zone was too expansive as compared to the area that is accessible to them (20 to $30 \%$ ). There was no significant difference between villages regarding this question $(p=$ 0.25). According to the forest management contract implemented between the local communities, forest administration, and project developer, the extraction of timber and burning of fallow for agricultural land was no longer free, and exploitation fees were fixed for each amount of resource taken as well as for burning of fallow. Regarding this, $61 \%$ of the total respondents disagreed with the application of a forest resource gathering fee; 
Table 4. Perception toward the Makira conservation.

\begin{tabular}{|c|c|c|c|c|c|c|c|c|c|c|}
\hline \multirow{2}{*}{$\mathrm{S} / \mathrm{N}$} & \multirow{2}{*}{ Statement (In \%) } & \multicolumn{2}{|c|}{ V1 } & \multicolumn{2}{|c|}{ V2 } & \multicolumn{2}{|c|}{ V3 } & \multicolumn{2}{|c|}{ V4 } & \multirow{2}{*}{$\begin{array}{c}\mathbf{P} \\
\text { value }\end{array}$} \\
\hline & & Agree & Disagree & Agree & Disagree & Agree & Disagree & Agree & Disagree & \\
\hline 1 & Forest cover has been declined over the past decades & 79.5 & 20.4 & 86.9 & 13.05 & 80.8 & 19.2 & 82.6 & 17.4 & 0.64 \\
\hline 2 & Livelihoods are affected by the forest decline & 72.7 & 27.3 & 69.6 & 30.4 & 65.4 & 34.6 & 78.3 & 21.7 & 0.45 \\
\hline 3 & Establishing the PA is necessary to sustain the forest in your area & 54.5 & 45.5 & 65.2 & 34.8 & 61.5 & 38.5 & 60.9 & 39.1 & 0.18 \\
\hline 4 & It is the responsibility of the local people to protect the surrounding forests & 54.5 & 45.4 & 78.3 & 21.7 & 73.1 & 26.9 & 65.2 & 34.8 & 0.1 \\
\hline 5 & Restriction measure must be implemented to sustain the forest & 40.9 & 59.1 & 63.0 & 37. & 57.7 & 42.3 & 45.7 & 54.4 & $0.035^{*}$ \\
\hline 6 & Resource extraction fees are necessary to sustain the resources & 27.3 & 72.7 & 43.5 & 56.5 & 46.2 & 53.9 & 34.8 & 65.2 & 0.05 \\
\hline 7 & The implementation of the strict conservation zone is perquisite for the efficiency of the conservation & 36.4 & 63.6 & 39.1 & 60.9 & 42.3 & 57.7 & 41.3 & 58.7 & 0.25 \\
\hline 8 & The forest management system solved the conflict over the forest & 54.5 & 45.4 & 63.0 & 37.0 & 61.5 & 38.5 & 56.5 & 43.5 & 0.065 \\
\hline
\end{tabular}

however, the number of respondents against this policy was significantly higher in V1 than V4 (72 and $65 \%$, respectively; $p=0.04)$. These people suggested that fixing the quantity of resources that can be harvested within a given period should already be sufficient as a restrictive measure without including extraction fees. They claimed that this practice gives more rights to the people that are able to pay the extraction fee and allows them to take more resources than the people who cannot pay this fee, thereby creating unequal access rights.

\section{Local perception towards community forestry and the project}

Among the surveyed local residents, $56 \%$ of the respondents claimed not to be satisfied with the rights provided to them by the forest user and emphasized that the period of time that they were allowed to collect resources was very limited (Table 5). The local people in the study area shared the same opinion about the low level of involvement of local people in the decision making process regarding the forest $(p=0.08)$, however, this differed by gender $(p=0.03)$, educational level $(p<0.01)$, annual income $(p<0.01)$, and age $(p=$ 0.03 ). Elder men that were more educated and had higher income comparing with the average were those who stated to be satisfy.

To strengthen the communities know-how, improve their livelihood, several capacity building related project were initiated and implemented by the project developer according to the needs and necessity of the local community. The capacity building included training for agricultural improvement, initiation for project management, training on the sustainable management of the natural resources, and training regarding income source diversification. The perception toward capacity building being developed by the project was statistically different between the villages $(p=$ 0.01 ) and between the educational levels ( $p<$ 0.01 ). Among all respondents from the four villages, $31 \%$ benefited from the capacity building being initiated and developed by the project, while the rest of the respondents (69\%) did not. Based on these responses, we found that a low level of understanding of the local people (44\%) and a lack of awareness (31\%) were the main reasons for not adopting the training given by the project developer. The third reason was simply a lack of motivation to adopt a new technique (25\%).
Regarding the functions within the forestry community, $60 \%$ of the respondents claimed that the decision making was too centered among the committee management members so that majority of the local people were left behind, and therefore these respondents were not satisfied with the functioning of their COBA. Taking into account the previous parameters affecting the attitude of the local people toward the Makira forest conservation project, $48 \%(n=89)$ of the total interviewed respondents were willing to support and participate within the forest conservation activities, while $53 \%(n=99)$ were reluctant to support the conservation project. The percentage of respondents that had a positive attitude toward the project differed significantly across the villages $(p$ $=0.04$ ), with the lowest percentage of respondents for V1 (39\%) and V4 (41\%).

The satisfaction level regarding participation in the implementation of activities differed between villages $(p=0.03)$, which can be explained by the fact that more activities were implemented within the V2 and V3 than V1 and V4. Selected as a pilot village in the Makira project, V2 benefited from greater conservation and development than the other villages. This satisfaction level also differed by gender $(p<0.01)$ and age $(p<0.01)$. 
Table 5. The perception of the local people toward the community forestry.

\begin{tabular}{|c|c|c|c|c|c|c|c|c|}
\hline Statement & $\begin{array}{l}\text { V1 (\%) } \\
\mathrm{n}=44\end{array}$ & $\begin{array}{l}\text { V2 (\%) } \\
n=46\end{array}$ & $\begin{array}{l}\text { V3 (\%) } \\
n=52\end{array}$ & $\begin{array}{l}\text { V4 (\%) } \\
n=46\end{array}$ & Total (\%) & df & $x^{2}$ & $\mathbf{p}$ \\
\hline \multicolumn{9}{|c|}{ To what extend are you satisfied with the forest user's right provided to your community } \\
\hline Very satisfied & 8.2 & 11.8 & 10.0 & 10.0 & 10.00 & & & \\
\hline Somewhat satisfied & 20.5 & 29.8 & 34.4 & 24.0 & 27 & 4.523 & 3 & 0.21 \\
\hline Not satisfied & 71.4 & 58.5 & 55.6 & 66.0 & 63 & & & \\
\hline \multicolumn{9}{|c|}{ To what extent are you satisfied with the functioning of your COBA } \\
\hline Very satisfied & 11.4 & 23.9 & 28.9 & 23.9 & 22 & & & \\
\hline Somewhat satisfied & 25.0 & 30.4 & 30.8 & 26.0 & 28 & 5.848 & 3 & 0.125 \\
\hline Not satisfied & 63.6 & 45.7 & 40.4 & 50.0 & 50 & & & \\
\hline \multicolumn{9}{|c|}{ To what extend are you satisfy with the involvement of the local people in the decision making process regarding the forest } \\
\hline Very satisfied & 12.2 & 18.2 & 13.3 & 14.0 & 14 & & & \\
\hline Somewhat satisfied & 26.5 & 34.1 & 33.3 & 20.0 & 28.5 & 8.559 & 3 & 0.08 \\
\hline Not satisfied & 61.2 & 47.7 & 53.3 & 66.0 & 57.5 & & & \\
\hline \multicolumn{9}{|c|}{ To what extend are you satisfy with the participation of the local people within forest conservation activities or development activities } \\
\hline Very satisfied & 10.2 & 25.0 & 20.0 & 16.0 & 18 & & & \\
\hline Somewhat satisfied & 16.3 & 29.5 & 33.3 & 22.0 & 25 & 14.650 & 3 & 0.03 \\
\hline Not satisfied & 73.5 & 45.5 & 46.7 & 62.0 & 57 & & & \\
\hline \multicolumn{9}{|c|}{ To what extent are you satisfied with the development project implemented within the forest conservation program to improve your well being } \\
\hline Very satisfied & 4.1 & 20.5 & 17.8 & 14.0 & 14 & & & \\
\hline Somewhat satisfied & 12.2 & 34.1 & 35.5 & 20.0 & 25.5 & 20.868 & 3 & 0.00 \\
\hline Not satisfied & 83.7 & 45.4 & 46.7 & 66.0 & 60.5 & & & \\
\hline \multicolumn{9}{|c|}{ To what extend are you satisfied with the capacity building provided by the project } \\
\hline Very satisfied & 8.2 & 27.3 & 22.2 & 10.0 & 17 & & & \\
\hline Somewhat satisfied & 14.3 & 31.8 & 33.4 & 20. & 25 & 18.559 & 3 & 0.01 \\
\hline Not satisfied & 77.6 & 40.9 & 44.4 & 70.0 & 58 & & & \\
\hline
\end{tabular}


Table 6. Regression model of factors that determine the positive attitude toward the forest conservation project.

\begin{tabular}{lccccc}
\hline Variable & B & SE & Wald & df & p \\
\hline Village & - & - & 8.394 & 3 & 0.04 \\
Gender (female) & 0.201 & 0.159 & 17.374 & 1 & $<0.01$ \\
Age $(>=55)$ & 1.401 & 0.294 & 22.679 & 1 & $<0.01$ \\
Cash income & 0.186 & 0.367 & 0.257 & 1 & 0.61 \\
Land ownership & 1.020 & 0.442 & 16.002 & 1 & 0.01 \\
Education level (>6years) & 1.762 & 0.403 & 19.071 & 1 & $<0.01$ \\
Wealth stratum & - & - & 9.318 & 2 & 0.06 \\
Use of forest resources & 0.460 & 0.345 & 18.389 & 1 & $<0.01$ \\
Perception of forest use & 1.507 & 0.303 & 24.819 & 1 & $<0.01$ \\
Benefit from project & 0.404 & 0.093 & 18.887 & 1 & $<0.01$ \\
Capacity building & 0.201 & 0.159 & 1.595 & 1 & $<0.01$ \\
\hline
\end{tabular}

Participation of men between the ages of 40 to 55 was more considerable. In addition, $39.5 \%$ of the total respondents interviewed stated that they were satisfied (very satisfied and somehow satisfied) with the development project that was implemented within the forest conservation, while the rest $(60.5 \%)$ were not satisfied.

\section{Logistic regression model of variables associated with a supportive attitude toward the forest conservation system}

The logistic regression analysis in Table 6 indicated that respondents from V2 and V3 were more likely to have a supportive attitude toward the forest conservation project than V1 and V4 $(p=0.03)$, since they were more involved and received more benefits than the other villages $(p<$ 0.01). Respondents who had a more favorable attitude were more likely to have a protective perception of the forest $(p<0.01)$, be satisfied with the rights for forest use $(p<0.01)$, have participated in capacity building $(p<0.01)$, and not be economically affected by the conservation measure of the forest $(p=0.03)$. Among the socioeconomic characteristics of the respondents, gender $(p<0.01)$, age $(p<0.01)$, and education level $(p<0.01)$ were associated with a favorable attitude toward the forest conservation. For this parameter, $68 \%$ of the female respondents were willing to support the forest conservation project, while only $45 \%$ of the male respondents supported the project. This can be explained by the fact that women perceived the forest as less important than men, since women see the forest mainly as a source of raw material for handicrafts and consumption, while men see the forest as an important source of their livelihood, particularly for those that mine gold. In addition, men use the forest resources for income generation, including carpentry, traditional boat manufacturing, and house construction. Aside from gender, age and the education level of the local people were associated with their supportive attitude toward the forest conservation project. Land ownership was also found to be associated with a positive attitude toward the forest conservation project $(p<0.01)$, and residents that owned more land ( 3 to $4 \mathrm{ha}$ ) had a more favorable perception of the project than those who owned less.

\section{DISCUSSION}

\section{Reasons for supporting the forest conservation project}

Of the respondents who supported the forest conservation project $(47 \%, n=89)$, the reason given for the support differed across the villages ( $p=0.03$; Table 7). Forty-two percent of these respondents $(n=37)$ indicated that the most important reason was the promotion of the local development by the project, which represented $20 \%$ of the total respondents $(n=188)$. However, the proportion of the respondents supporting this perception differed between villages $(p<0.01)$. None of the respondents from V1 supported this reason, since no development project had yet been implemented by the project in that village: there is few projected implemented but the local people didn't perceive any benefit or any change in their life ,( the implemented project was not effective enough to change the perception of the local people), while in V2, 54\% of the households that favored the project also supported this opinion. This perception did not differ by gender $(p=0.69)$ or by educational level $(p=0.26)$, while it did differ by land ownership $(p=0.03)$ and income $(p=0.04)$. Households that owned more land seemed to get more benefit from the training for agricultural improvements than everyone owns land but those that own more got more benefit (benefit from the agricultural training) land. For example, there was a $20 \%$ increase in rice yields among the households that possessed more than 2 ha of rice fields, and this increase was generated by the application of the System of Rice Intensification (SRI). Training for the 
Table 7. Reasons for supporting the forest conservation project.

\begin{tabular}{|c|c|c|c|c|c|c|c|}
\hline Reason & $\begin{array}{c}\text { V1 } \\
n=17 \\
(38.6 \%)\end{array}$ & $\begin{array}{c}\text { V2 } \\
n=25 \\
(54.3 \%)\end{array}$ & $\begin{array}{c}\text { V3 } \\
n=28 \\
(53.8 \%)\end{array}$ & $\begin{array}{c}\text { V4 } \\
n=19 \\
(41.3 \%) \\
\end{array}$ & $x^{2}$ & df & p \\
\hline Solution for land ownership conflict & 11.8 & 12.0 & 17.7 & 15.8 & 5.04 & 3 & 0.17 \\
\hline Promotion of local development (\%) & 0.0 & 60.0 & 53.6 & 36.9 & 19.87 & 1 & $<0.01$ \\
\hline Generation of direct income (\%) & 5.9 & 12.0 & 10.7 & 10.5 & 4.86 & 3 & 0.26 \\
\hline Promotion of local participation & 17.7 & 12.0 & 7.1 & 15.8 & 5.64 & 3 & 0.23 \\
\hline Improvement of the natural environment (\%) & 64.7 & 4.0 & 10.7 & 21.0 & 14.67 & 3 & 0.03 \\
\hline
\end{tabular}

Table 8. Reason for not supporting the Makira conservation project.

\begin{tabular}{lccccccc}
\hline Reason & $\begin{array}{c}\mathbf{V} \mathbf{1} \\
\mathbf{n = 2 7} \\
\mathbf{( 6 1 . 4 \% )}\end{array}$ & $\begin{array}{c}\mathbf{V} \mathbf{n}=\mathbf{2 1} \\
\mathbf{( 4 5 . 7 \% )}\end{array}$ & $\begin{array}{c}\mathbf{V} \mathbf{n}=\mathbf{2 4} \\
\mathbf{( 4 6 . 2 \% )}\end{array}$ & $\begin{array}{c}\mathbf{V} \mathbf{n}=\mathbf{2 7} \\
\mathbf{( 5 8 . 7 \% )}\end{array}$ & $\mathbf{X}^{\mathbf{2}}$ & $\mathbf{d f}$ & $\mathbf{p}$ \\
\hline No benefit for me and my family (\%) & 48.0 & 16.7 & 20.0 & 50.0 & 14.05 & 1 & 0.04 \\
Loss of right over forest (\%) & 40.0 & 33.3 & 30.0 & 25.0 & 5.85 & 36 & 0.15 \\
Generate interest conflict (\%) & 0.0 & 41.7 & 30.0 & 12.5 & 18.43 & 6 & 0.03 \\
Exclusion of local people (\%) & 8.0 & 8.3 & 10.0 & 6.3 & 12.86 & 6 & 0.18 \\
Lack of awareness (\%) & 4.0 & 0.0 & 10.0 & 6.2 & 6.36 & 9 & 0.52 \\
\hline
\end{tabular}

application of this SRI was provided by the project developer, but only a few households adopted the technique $(32.5 \%)$, and the main reason given for not adopting this new agricultural system was a lack of understanding (51\%) and lack of awareness (17\%).

The second reason given to support the project was the improvement of the natural environment (rain, soil fertility, and drinking water), which was supported by $20 \%(n=19)$ of these respondents and represented $10 \%$ of the total number of individuals interviewed. This opinion differed by age $(p<0.01)$ and education level $(p=0.02)$. Compared with young and middle age, older and more educated community member stated to be more concerned with the ecosystem function of the forest rather than the other benefit from the conservation of the forest. The third reason given was the minimization of the conflict over the forest land and forest resources since the implementation of the project, which was supported by $15 \%$ of these respondents and represented $7 \%$ of the total number of individuals interviewed. The proportion of the respondents sharing this idea did not differ between the villages $(p=$ $0.17)$.

\section{Reasons for not supporting the Makira conservation project}

Of the respondents who had a negative attitude toward the forest conservation project ( $53 \%$ of total, $n=99$ ), there was a statistically significant difference in the main reason given among the villages $(p=0.04)$; however, the most common reason given was the lack of a direct benefit from the project $(33.4 \%, n=35,2 \%$ of total) (Table 8 ). The proportion of the respondents supporting this reason differed between the villages $(p=0.04)$, with the highest proportion of respondents from V1 and V4. This opinion did not differ between sex, educational level, land ownership, or income of respondents $(p>0.05)$. A less important reason that did not differ between the villages $(p$ $=0.15$ ) was the feeling of losing the right of control over their own forest $(33 \%)$. This opinion differed based on land ownership $(p=0.03)$, education level $(p<0.01)$, and income $(p=0.05)$. The third reason given for not supporting the conservation project was that the project generated a conflict of interest among the local people $(19 \%, n=19)$.

The number of the respondents that reported this reason differed between the villages $(p=0.03)$, and this conflict of interest was claimed more by the respondents from V2 and V4, where several development projects have been implemented (training for agricultural improvement, construction of school, dam, ecotourism project, silk worm production, establishing tree nurseries, and others). These people argued that the benefits from the projects implemented were not equally shared among all community members.

Socioeconomic characteristics of the local people associated with their attitude toward the conservation project

Many studies have examined socioeconomic and 
demographic variables as predictors of attitudes towards protected areas in developing countries (Infield, 1988; Heinen, 1993; Newmark et al., 1993; Fiallo and Jacobson, 1995; Wang et al., 2006). The results in this study showed that majority of the respondents had a positive attitude toward conservation of the Makira forest; however, the attitude toward the conservation project was highly attributed to socioeconomic conditions, such as age, gender, literacy level, and land ownership. Based on the findings from this study, we can conclude that the more educated and older people were more confident to participate in the forest conservation project than the young and those with no education. The educated people also had more knowledge on forest conservation issues, which could result in frequent interactions with the project staff, and this type of interaction usually creates a mutual trust that promotes willingness to support the project. In most cases, the more educated people were those who were chosen to represent the community in the decision making process at the regional or national level, and therefore, they were more involved and engaged within the project. Because of this engagement, they clearly had some level of a willingness to support the project as compared to the others.

According to the survey results, the percentage of women who supported the conservation project was higher than men. This can be explained by the fact that women have less dependency on the forest than men, and the use of forest resources by women is generally limited to the collection of consumptive products and fiber for handicrafts. In contrast, the forest provides important resources for the livelihood of men, such as mining and the extraction of timber. Therefore, men are more affected by the restriction of the forest than women and thus less supportive of the conservation project.

Although, the annual cash income and the wealth stratum of the respondents was not associated with their attitude toward the project, land ownership was found to be one of the determining factors that affected the attitude of the residents, and because of this, people who owned more land ( 3 to $4 \mathrm{ha}$ ) tended to support the project and showed a willingness to participate. These people were not really affected by the restrictive measures of the project, since their dependency on forest resources was insignificant. In addition, people who owned more land perceived a tangible benefit from the training given by the project for the improvement of agricultural yields. Among all respondents, those who received some income from timber-related and mining activities were the most reluctant toward the forest conservation project.

\section{Benefits from the project influenced the attitude of local people}

It is widely accepted that the decision by people on whether to participate in the developmental activities or not is largely determined by perceived benefits (Miller, 1988; Pongquan, 1992; Dale, 2000). REDD is a concept by which reduction of emissions from deforestation and forest degradation can be compensated through payment of carbon credits. The results shown in this study indicated that most of the people that supported the forest conservation project were those who directly benefited from the forest conservation. As Poudyal (1990) pointed out, the higher the expectation of benefit from an activity, the higher the rate of participation will be. The respondents from V2 and V3, located in areas where efforts have addressed the livelihood needs of the local communities and encouraged sustainable practices (Infield, 1988; Newmark et al., 1993; Fiallo and Jacobson, 1995; Nepal and Weber, 1995; De Boer and Baquete, 1998; Gibson and Marks, 1995), represented the highest level of support, and more than $50 \%$ of the interviewed residents were willing to support the forest conservation project. In this study as well as potentially other areas, the people that benefited the most from the project (either through capacity building or direct employment) were found to be the people with more education or a socioeconomic advantage. These people were the elite at the local level, and although the jobs and benefits from these projects were available to everyone, majority of the local people were unable to take advantage of them for various reasons (Goodwin et al., 1998; Walpole and Goodwin, 2001). With the objective of selling carbon credit under REDD, the Makira forest offers a large opportunity for the improvement in the socioeconomic conditions of the local community and for natural resource conservation. Although, the project was implemented through community groups, the representation of poor households in the groups was negligible. This finding together with the project's inability to address disadvantaged groups' problems led to an exclusion of disadvantaged households from most of the benefits provided by the forest conservation project.

\section{Positive attitude toward the forest conservation project does not always translate success of conservation}

Attitudinal surveys have been used in many countries to assess the success of a conservation program (Fiallo and Jacobson, 1995; Infield and Namara, 2001), and it is hypothesized that a high percentage of local residents having positive attitudes toward conservation indicates forest conservation success. In this study, the percentage of respondents who favored conservation of the forest was $80.45 \%$; however, due to several reasons as shown in Table 7 , only $46 \%$ of the total respondents showed a willingness to support the forest conservation project, and of this sub-group, nearly $60 \%(n=53)$ were from V2 and V3 where the local residents had better socioeconomic conditions and did not depend on forest resources as 
much as residents from V1 and V4. Therefore, majority of the people that supported the conservation project were less affected by the restrictive measures implemented by the forest conservation project. This fact can be seen in Table 1 (socioeconomic characteristics), Table 2 (use of forest resources), and Table 3 (perception of the forest resources). If the majority of the respondents who had a positive attitude toward the project are those who had less interest in the resources of the PA, then it can be argued that a positive attitude does not necessarily translate into the success of the conservation project. If the support of the forest conservation project by local drivers, such as loggers and mine operators, remains low, then the success of this project remains questionable.

\section{CONCLUSION AND RECOMMENDATIONS}

This study attempted to explore how the socioeconomic factors, the perception regarding the forest and the forest resources, and the reception of benefits can influence the attitude and the perceptions of the local people toward forest management practices. The difference of perception is first determined by the dependency on the forest resources and then by the reception or not of individual benefit from the project. Most of the respondents were aware of the conservation of Makira forest, and more than half agreed with the necessity for conserving the forest; however, being well aware of and in agreement with the necessity of conserving the forest did not necessarily generate a positive attitude towards the forest conservation project. Depending on various factors, $46 \%$ of the residents interviewed held a positive attitude toward the forest management. Of these, the residents from Ambodivoangy and Marovovonana villages had a more positive attitude than residents from Andaparaty and Ambalamahogo. Residents from the latter two villages held negative perception toward the forest conservation practices, because a considerable proportion of the local people perceived the forest as an important source of livelihood, and few household claimed to receive direct benefits from the project. It is clear that the benefits from the project are unequally distributed, and that this inequality is recognized by the local people and influences their perception of and attitude towards the project. The low education level of the majority of the residents was found to be a barrier that prevented them from actively participating in the REDD structure implementation, and there is a need to develop language or communication skills that are understandable for every member of the local community. Since two decades, the people-centered management approach has been emphasized in several forest conservation policies and projects in most of the tropical countries, and yet due to differences in abilities, attitudes and perceptions of the forest community, securing active and equitable participation from all social layers remains a challenge for all forest conservation projects. As such to the extent possible, planners and managers must ensure fair and equitable distribution of benefits of a forest carbon project similar to REDD in order to succeed. To achieve this, the criteria for selecting the local community representatives should be more expanded to enable all layers of the local people to be represented and so that their voice can be heard. The promotion of active, self-organized, and self-governed involvement of local people is also needed, which will allow all of the layers of the local community to be involved.

The main reason for not disclosing the REDD issues to the local community in the case study and thus disable them to participate fully in the REDD implementation is the fear of creating false expectation to the local community since their capacity of understanding is very low, to overcome this, provision of information outlining details of how REDD mechanisms work, and providing realistic expectations of benefits, will be necessary to ensure 'voice and choice' in the negotiation of equitable agreements between national and local actor. New approaches may need to be sought to provide information about all relevant aspects in appropriate language and forms to raise awareness and support the capacities of indigenous and forest dependent communities to participate before any consultations start. In order to be truly democratic and participative, the forest governing bodies should reflect the social diversity within groups and represent the interests of all users.

\section{ACKNOWLEDGEMENTS}

Our deep thanks to everyone who brought their contributions to this paper, and for kindly sharing ideas, comments, and suggestions. Special thanks to the WCS Makira project team for providing support during our field-work. This research was financially supported by the Sasakawa Scientific Research Grant from The Japan Science Society.

\section{REFERENCES}

Adams W, Hulme D (2001). Conservation and community. In Hulme, David and Murphree, Marshall (eds). African Wildlife and Livelihoods. Oxford: James Currey Limited.

Agrawal A, Gibson C (1999). Enchantment and disenchantment: The role of community in natural resource conservation. World Dev. 27(4):629-649.

Alison O, Beth A, Kaplin A (2005). A framework for understanding community resident perceptions of Masoala National Park, Madagascar . Found. Environ. Conserv. 32(2):156-164. doi: 10.1017/S0376892905002146

Anderson J, Benjamin C, Campell B, Tiveau D (2006). Forests, poverty and equity in Africa: new perspectives on policy and practice. Int. For. Rev. 8(1):44-53

Brandon K, Redford KH, Sanderson SE (1998) .Parks in Peril: People, Politics, and Protected Areas. Washington DC, USA Island Press.

Dale R (2000). Organizations and Development- Strategies, Structures and Processes, Sage publications, New Delhi.

De Boer W, Baquate D (1998). Natural resource use, crop damage and 
attitudes of rural people in the vicinity of the Maputo Elephant Reserve, Mozambique. Environ. Conserv. 5(3):208-218.

FAO (2000). Global forest resources assessment. FAO Forestry Paper 140. Rome.

Ferraro PJ (2002). The local costs of establishing protected areas in low-income nations: Ranomafana National Park, Madagascar. Ecol. Econ. 43(2-3):261-275.

Fergusson HB (2009). REDD in Madagascar: An Overview of Progress, Independent Report, 5th November 2009. http://www.mwc-info.net/en/services/Journal_PDF's/Issue4-2/MCD_2 009_vol4_iss2_REDD_Supplementary_Material.pdf (accessed on December $19^{\text {th }}$ 2009)

Fiallo EA, Jacobson SK (1995). Local communities and protected areas: attitudes of rural residents towards conservation and Machalilla National Park, Ecuador. Environ. Conserv. 22(3):241-249.

Gibson CK, Marks SA (1995). Transforming rural hunters into conservationists: an assessment of community-based wildlife management program in Africa. World Dev. 23(6):941-957.

Gillingham S, Lee P (1999). The Impact of Wildlife-Related Benefits on The Conservation Attitudes of Local People Around the Selous Game Reserve, Tanzania. Environ. Conserv. 26(3):218-228.

Goodwin P (1998). Hired hands or local voice: understandings and experience of local participation in conservation. Transactions of the Institute of British Geographers, New Series 23:481-499.

Harada K (2003). Attitudes of local people towards conservation and Gunung Halimun National Park in West Java, Indonesia. J. Forest Res. 8:271-282.

Heinen JT (1993). Park-people relationships in Kosi Tappu Wildlife Reserve, Nepal: a socio-economic analysis. Environ. Conserv. 20(1):25-34

Holmes C (2007). Linking Livelihoods, Land Stewardship, and Resource Conservation in the Antongil Bay Landscape, Madagascar. In Protected areas and human livelihoods, edit., Redford and Fearn Eva. WCS Working Paper. 32

Holmes C, Crowley H (2007). Makira Forest Protected Area. Interim Report to the Center for Environmental Leadership in Business, Conservation International.

Infield M. (1998). Attitudes of a rural community towards conservation and a local conservation area in Natal South Africa. Biol. Conserv. 45:21-46.

Jaozandry JJ, Holmes C (2005). Makira Forest Conservation Area Project - Annual Progress Report, July 12004 - June 302005

Kramer R, Van SC, Johnson J (1997). Last Stand: Protected Areas and the Defense of Tropical Biodiversity. New York, USA: Oxford University Press.

Mehta J, Kellert S (1998). Local attitudes toward community based conservation policy and programmes in Nepal: a case study in the Makalu-Barun Conservation Area. Environ. Conserv. 25(4):320-333.

Meyers D (2008). Lead consultant on IRG study of Makira Forest Project. Personal communication.
Nepal SK, Weber KE (1995). Prospects for coexistence: wildlife and local people. Ambio 24:238-245.

Newmark WD, Leonard NL, Sariko HI, Gamassa DGM (1993). Conservation attitudes of local people living adjacent to five protected areas in Tanzania. Biol. Conserv. 63:177-183.

Ormsby A (1996). An attitudinal survey of resident perceptions of conservation at Five Blues Lake National Park, Belize. TRI News. J. Trop. Res. Inst. 15(1):13-15.

Ostrom E (1999). Self Governance and Forest Resources. Center for International Forestry Research (CIFOR) Discussion paper No. 20.

Pimbert MP, Pretty JN (1995). Parks, People and Professionals: Putting 'Participation' into Protected Area Management. Geneva, Switzerland: United Nations Research Institute for Social Development.

Pongquan S (1992). Participatory Development Activities at Local level: Case studies in Villages of Central Thailand Bangkok, Thailand.

Poudyal LP (1990). People involvement in Planned District Development Thropugh Decentralization in Nepal, Doctorat Dissertation, HS-90-2, Asian institute of Technology, Bangkok.

Roberstson J, Lawes M (2005). User Perceptions of Conservation and Participatory Management of Igxalingenwa Forest, South Africa. Environ. Conserv. 32(1):64-75.

Scherl LM, Wilson A, Wild R, Blockhus J, Franks P, McNeely JA, McShane TO (2004). Can Protected Areas Contribute to Poverty Reduction? Opportunities and Limitations. Chief Scientist's Office Report, IUCN, Gland.

USAID (2006). Issues in Poverty Reduction and Natural Resource Management. United States Agency for International Development, Washington, DC

Walpole M, Goodwin H (2001). Local Attitudes toward Conservation and Tourism around Komodo National Park, Indonesia. Environ. Conserv. 28(2):160-166.

Wang SW, Lassoie JP, Curtis PD (2006). Farmer attitudes towards conservation in Jigme Singye Wangchuck National Park, Bhutan. Environ. Conserv. 3(2):148-156.

Wells M., Brandon K, Hannah L (1992). People and Parks: Linking Protected Area Management with Local Communities. World Bank / USAID / WWF-US, Washington DC.

Wiggins S, Kofi Marfo, Anchirinah V (2004). Protecting the Forest or the People? Environmental Policies and Livelihoods in the Forest Margins of Southern Ghana. World Dev. 32(11):1939-1955.

World Bank (2000). World Development Report: Attacking Poverty. World Bank, Washington DC. 